\title{
GREECE FINANCIAL CRISES AND SUKUK MARKETS: EXPERIENCE FROM GULF COUNTRIES
}

\author{
Aldrin Herwany ${ }^{1}$, Erie Febrian ${ }^{2}$, Imam Buchari ${ }^{3}$
}

\begin{abstract}
Greece Financial Crises and Sukuk Market: Experience From Gulf Countries. Many studies have been carried out to investigate the impact of recent European financial crises on the performance of financial instruments in other regions. Nevertheless, there have been insufficient studies explaining such impact on Islamic financial instrument. In particular, whether Greece Financial crises have affected performance of Sukuk traded in Gulf Markets needs to be answered. This study is aimed at empirically investigating the causality of credit and liquidity risk on Sukuk Markets in Gulf economies in the period of Greece Financial Crises. We analyzed the Sukuk data by employing Granger casuality test, with all the associated vector autoregression model procedures. Our findings show that Bahrain sukuk market is cointegrated with those of Qatar and UAE in the full period observation. Meanwhile, during the crisis, Qatar Sukuk market is cointegrated with those of UAE Bahrain. We also find that Bahrain Sukuk triggers market shock in both Qatar and UAE Sukuk markets. Bahrain consistently causes changes in price and spread of UAE Sukuk, both in the context of the full period and the during-crisis period.
\end{abstract}

Keywords: Greece financial crises, sukuk markets, gulf countries

\begin{abstract}
Abstrak. Krisis Keuangan Yunani dan Pasar Sukuk: Pengalaman dari Negara-negara Teluk. Banyak penelitian yang telah dilakukan untuk menginvestigasi dampak yang terjadi pada krisis instrumen keuangan di wilayah eropa pada wilayah lain. Meski demikian, sedikit penelitian yang menjelaskan tentang dampak yang terjadi pada instrument keuangan Islam. Khususnya, apakah krisis moneter yunani telah mempengaruhi kelangsungan perdagangan sukuk di pasar gulfmembutubkan jawaban. Penilitian ini secara empiris bertujuan untuk meneliti resiko pada kredit dan likuiditas dalam pasar sukuk di perekonomian teluk pada masa krisis moneter yunani. Kami meneliti data sukuk menggunakan test Granger kasualitas, dengan segala hal yang terkait prosedur model autoregresi. Penelitian kami memperlihatkan bahwa pasar sukuk di Bahrain terkointegrasi dengan Qatar dan UAE dalam masa penelitian penuh. Kami juga menemukan bahwa Suku Bahrain Mengejutkan Pasar pada Qatar maupun UAE. Bahrain secara konsisten menyebabkan perubahan pada harga dan menyebar ke sukuk UAE, dalam konteks masa penuh maupun pada masa krisis terjadi.
\end{abstract}

Kata kunci: krisis moneter Yunani, pasar sukuk, negara teluk

\footnotetext{
Received: September 18, 2016; Revised: October 23, 2016; Accepted: December 13, 2016

1,2 Universitas Padjajaran, Jl. Dipati Ukur, Lebak Gede, Bandung, West Java

${ }^{3}$ University College of Bahrain, Manama, Kingdom of Bahrain

Email: 'aldrin.herwany@fe.unpad.ac.id; ${ }^{2}$ erie_febrian@fe.unpad.ac.id; ${ }^{3 i b u c h a r i @ u c b . e d u . b h ~}$

DOI: 10.15408 /aiq.v9i1.3773
} 


\section{Introduction}

Some scholars, like Stiglitz (2012), believe that Greece crisis was a contagious impact from the US financial crisis. The crisis may have broadened to other regions outside Europe through similar process since financial products traded in Greece market are also traded in other markets outside Europe, and investors have greater and easier opportunities to access overseas markets and form international portfolio. The nature of financial products and investor characteristics are, among others, factors that explained the smooth transfer of the calamity.

There have been many studies carried out to investigate the transfer of crisis from the USA to Greece and from Greece to other regions, such as Pragidis et.al (2015). Nevertheless, there have been insufficient studies done to elaborate the impact of Greece crisis on other markets or financial products. This study aims to fill this literature gap. To be more particular, this study intends to assess the contagious impact of Greece crisis to Gulf market, especially in Sukuk markets. We propose an assessment of the contagion issue using data of Islamic financial/capital products, such as: Sukuk, since this product is believed to be free of interest and, therefore, may relatively be immune to the impact of financial shock.

Based on the above concern, it is important to check whether there is cointegration and causality among markets in the same region, and which market is the entry gate of shock in the region. By answering these questions, we can reveal long run cointegration between markets in Gulf economies and its magnitude when Greece crisis enters the region. We also need to know whether there are pressures on price and bid-ask spread in a downturn environment, since price and spread reflect investor trading behavior in particular financial product.

\section{Literature Review}

Islamic capital products and Islamic financial system will advance significantly, including Sukuk. Sukuk has been perceived to bear relatively lower risk than Bond (Kumar, 2014). Malaysia dominates international Sukuk market by seizing 71\% market share. The amazing increase in Ijarah Sukuk trading volume in Malaysia is due to growing perception that Sukuk is immune to crisis. Bhala (2012) explains that Sukuk is more flexible to anticipate the wave of crisis since Sukuk introduces lesse-lessor relationship, instead of lender-borrower relationship. Such a nature of Sukuk helps the holder face uncertainty in more flexible manner.

Nevertheles, that flexibility does not guarantee high trading record. Investors show varied consideration and attitudes toward investment opportunity. Risk and 
return trade-off, for instance, may lead investors to different buy-sell strategy. Besides, Sukuk bears the issuer's default risk as unexpected event may occur (Zakaria, et.al, 2012).

Some cointegration tests have been done to explain investment patterns Granger and Hilman (1991). Herwany and Febrian (2008), Febrian and Herwany (2009) have carried out empirical investigation to reveal cointegration among seven markets in Asia. In Latin America, Auyong, Gan and Treepongkaruna (2004) proved causality and cointegration among markets, particularly in the crisis environment starting from Mexico (1994) to Asia (1997), Rusia (1998) and Brazil (1999). Despite contra-argument that introduced by Pragidis et.al. (2015), who found no contagion effects from Greece crisis to other region, using volatility model, the impact of crisis in the long run can be identified through cointegration and causality test.

Meanwhile, Friewald et.al. (2012) done a similar study using data of corporate bond sduring the 2008 crisis. Aboody, et.al (2014) also conduct a study evaluating contagion impact in bond market during crisis. Using Asia Bond Market, Guillaumin (2009) finds that financial integration is stronger in the psot-crisis period than during the crisis. Similarly, a study by Shin and Kim (2015) reveal the strong liquidity effect and credit risk in the post-crisis period. In their study, Friewald et.al (2012) introduce the importance of liquidity, represented by bid-ask spread, to explain investor behavior and bond price movement. This study adopts the idea to reveal the financial crisis contagion to Sukuk Gulf markets by assessing the associated price changes and liquidity.

\section{Methods}

In this study, we employ data of Ijarah sukuk issued by three Gulf countries, i.e., Qatar, Uni Arab Emirate and Bahrain. The data, obtained from Bloomberg, consists of sukuk price, bid price, and ask price. Spread figures are the difference between bid and ask prices. As Greek crisis had occured during the period of 20092012, we conducted the observation using data from 2012.7 to 2013.12. Thus, this study utilized 519 observations. We divided the second observation period based on the decline of Sukuk price, in which the cut-off date is 24 May 2013, as can be seen on the Figure 1 and 2.

Figure 1 shows sharp decline in the Al-Ijarah Sukuk price in the three observed economies, i.e., Qatar, UAE and Bahrain, starting from 24 May 2013. The prices recovered in the mid of the third quarter 2013. The decline was followed by the increase in spread volatility of the Suku as depicted by Figure 2. 
Al-Iqtishad: Jurnal Ilmu Ekonomi Syariah (Journal of Islamic Economics) Vol. 9 (1), January 2017

Figure 1. Daily Price Series of Qatar, UAE, and Bahrain Sukuk

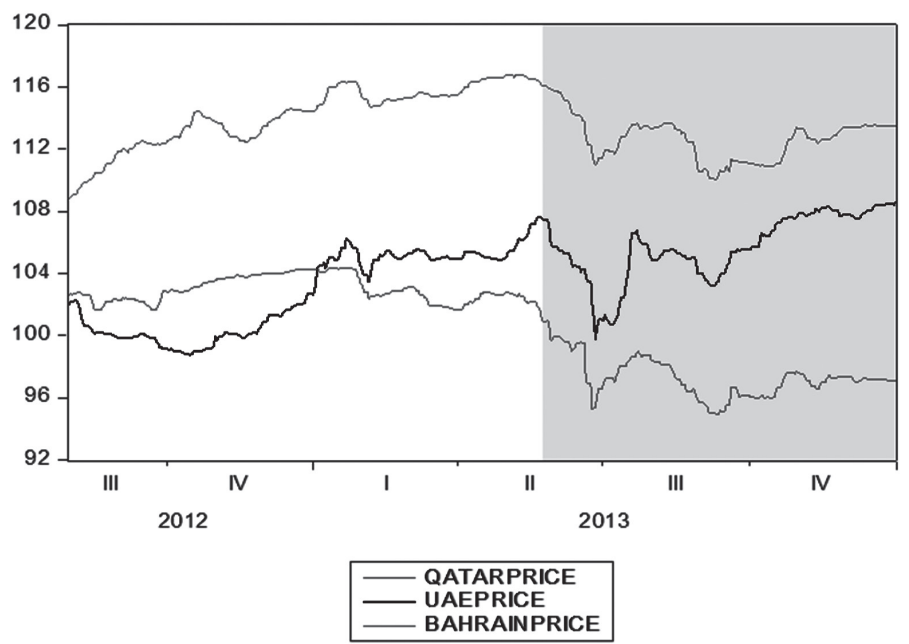

Source: Processed Data

Figure 2. Daily Spread Series of Qatar, UAE, and Bahrain Sukuk

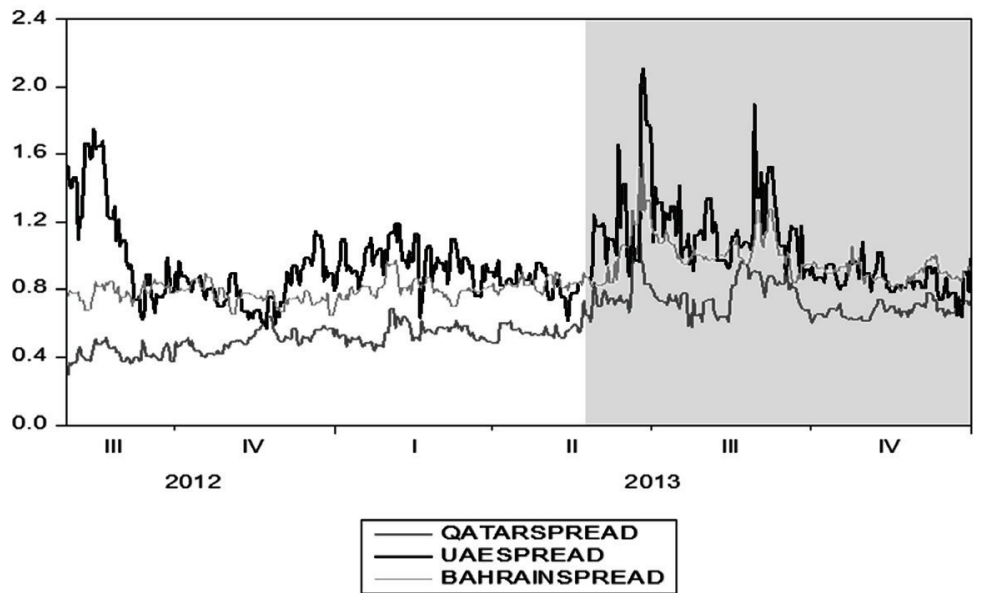

Source: Processed Data

Figure 3 shows that both price and spread of Al Ijarah Sukuk experienced sharp increase in volatility in 2013s. 
Figure 3. Price and Spread of Sukuk AL-Ijaraah
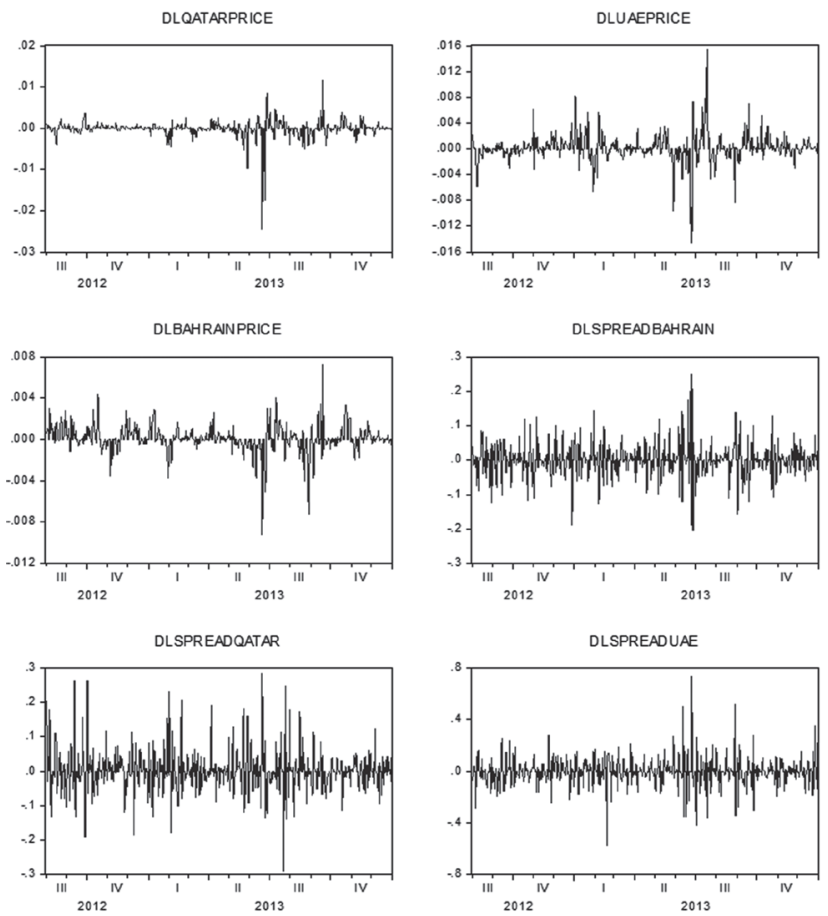

Source: Processed Data

After describing big picture of the raw data and particular movements of price and spread of Ijarah Sukuk in the three economies, we checked the correlation between the observed economies. We also conducted cointegration test to estimate the price movements in the long term using Cointegration model and Vector Error Correction Model (VECM), which followed VAR test and Augmented Dickey Fuller (ADF) Test.

In addition to the cointegration test, we also assess causality relationship among the three economies to reveal the impact magnitude of a shock occurring in one country to another. In this process, we followed Granger-Causality test procedure.

\section{Result and Discussion}

The descriptive statistics is divided into two parts. The first part is related to price of Sukuk of the three economies. In general, the average price of UAE and Bahrain Sukuk is positif, while that of Qatar is negative. Price spread of Qatar Sukuk is the largest, as can be seen from its balance of maximum and minimum prices. Standard deviation of Qatar Sukuk price is also the highest, indicating the high risk. On the other hand, Bahrain sukuk Price indicates the lowest risk 
(standard deviation of 0.0013). Based on the spread (Ask - Bid), Qatar Sukuk shows the highest risk level (0.1069).

Table 1. Price and Spread of Al-Ijarah Sukuk

\begin{tabular}{lcccccc}
\hline & $\begin{array}{c}\text { QATAR } \\
\text { PRICE }\end{array}$ & $\begin{array}{c}\text { UAE } \\
\text { PRICE }\end{array}$ & $\begin{array}{c}\text { BAHRAIN } \\
\text { PRICE }\end{array}$ & $\begin{array}{c}\text { SPREAD } \\
\text { BAHRAIN }\end{array}$ & $\begin{array}{c}\text { SPREAD } \\
\text { QATAR }\end{array}$ & $\begin{array}{c}\text { SPREAD } \\
\text { UAE }\end{array}$ \\
\hline Mean & -0.000 & 0.000 & $8.04 \mathrm{E}-05$ & 0.000 & 0.002 & -0.001 \\
Median & 0.0000 & 0.0000 & 0.0000 & 0.000 & 0.000 & 0.000 \\
Maximum & 0.012 & 0.015 & 0.007 & 0.251 & 0.285 & 0.735 \\
Minimum & -0.025 & -0.015 & -0.009 & -0.205 & -0.292 & -0.576 \\
Std. Dev. & 0.002 & 0.002 & 0.001 & 0.047 & 0.060 & 0.107 \\
Skewness & -4.764 & -0.248 & -1.083 & 0.171 & 0.764 & 0.450 \\
Kurtosis & 62.877 & 17.653 & 14.247 & 7.488 & 7.999 & 11.491 \\
Jarque-Bera & 7934 & 4639.5 & 2831.6 & 437.24 & 589.71 & 1573.6 \\
Probability & 0.000 & 0.000 & 0.000 & 0.000 & 0.000 & 0.000 \\
Sum & -0.055 & 0.063 & 0.042 & 0.1769 & 0.905 & -0.437 \\
Sum Sq. Dev. & 0.002 & 0.002 & 0.000 & 1.143 & 1.862 & 5.905 \\
Observations & 518 & 518 & 518 & 518 & 518 & 518 \\
\hline
\end{tabular}

Source: processed Bloomberg data

All the above sukuk data is in differencing and log. Spread is the balance between bid and ask Al Ijarah Sukuk.

The correlation matrix demonstrates that relationship of any two of the three observed economies indicates relatively low correlation with correlation coefficients ranging from $0.44 \mathrm{~s} / \mathrm{d} 0.66$. This implies that in the short term, a portfolio involving these Sukuks might be less risky.

Table 2. Correlation Matrix of Al Ijarah Sukuk

\begin{tabular}{lcccccc}
\hline & $\begin{array}{c}\text { QATAR } \\
\text { PRICE }\end{array}$ & $\begin{array}{c}\text { UAE } \\
\text { PRICE }\end{array}$ & $\begin{array}{c}\text { BAHRAIN } \\
\text { PRICE }\end{array}$ & $\begin{array}{c}\text { BAHRAIN } \\
\text { SPREAD }\end{array}$ & $\begin{array}{c}\text { QATAR } \\
\text { SPREAD }\end{array}$ & $\begin{array}{c}\text { UAE } \\
\text { SPREAD }\end{array}$ \\
\hline QATAR PRICE & 1.000 & 0.460 & 0.615 & -0.318 & -0.272 & -0.070 \\
UAE PRICE & 0.460 & 1.000 & 0.445 & -0.178 & -0.074 & -0.207 \\
BAHRAIN PRICE & 0.615 & 0.445 & 1.000 & -0.166 & -0.109 & -0.161 \\
BAHRAIN SPREAD & -0.318 & -0.176 & -0.166 & 1.000 & 0.166 & 0.009 \\
QATAR SPREAD & -0.272 & -0.074 & -0.109 & 0.166 & 1.000 & 0.006 \\
UAE SPREAD & -0.070 & -0.207 & -0.161 & 0.009 & 0.006 & 1.000 \\
\hline
\end{tabular}

Source: processed Bloomberg data

All the above sukuk data is in differencing and log. Spread is the balance between bid and ask Al Ijarah Sukuk. 
Before testing the causality, we run ADF test on Sukuk price and and Sukuk spread to check the data stationarity. The result of ADF test confirms that all the Sukuk time series is stationary at the first differencing with high ADF stat.

Table 3. ADF test

\begin{tabular}{lcc}
\hline Al-Ijarah Sukuk & ADF-Stat & Differencing \\
\hline Price (QATAR) & $-9.494^{* * *}$ & 1 \\
Price (UAE) & $15.007^{* * *}$ & 1 \\
Price (BAHRAIN) & $-13.916^{* * *}$ & 1 \\
Spread (Qatar) & $-25.964^{* * *}$ & 1 \\
Spread (UAE) & $-28.271^{* * *}$ & 1 \\
Spread (BAHRAIN) & $-28.778^{* * *}$ & 1 \\
\hline
\end{tabular}

Source: processed Bloomberg data

All the above sukuk data is in differencing and log. Spread is the balance between bid and ask Al Ijarah Sukuk.

Table 4 shows the results of VEC test in three observation periods, i.e., full period, crisis period and sukuk price decline. The first column is the change of Qatar sukuk price. The lag 1 of the change of sukuk price of Qatar, UAE, Bahrain and the residual of the original equation become dependent variables. The table indicates that Bahrain Sukuk price consistently and significantly puts pressure on those of Qatar and UAE in the full period observation, with coefficients of 0.398 and 0.200 , respectively. This pressure also exists in the Crisis observation period and in the Price-Decline observation period.

Table 5 demonstrates longterm equilibrium relationship, obtained from the VEC model test. It can be seen that Bahrain sukuk price is cointegrated with those of Qatar and UAE, significantly at $1 \%$, in the full period observation. Meanwhile, in the crisis-period observation, Qatar Sukuk price is cointegrated with that of UAE and signifianct at $5 \%$ level, and with that of Bahrain and significant at $1 \%$ level.

In the price-decline observation period, UAE Sukuk price cointegrates with that of Bahrain, as well as cointegrates with that of Qatar at $1 \%$ significance level It can be implied from the above results that Bahrain price consistently cointegrates with that of Qatar, meaning that Bahrain price provides the largest contribution to the change of the other two Sukuk prices. It can be inferred from this empirical fact that the dominant market shock is Bahrain sukuk price. 
Table 4. VEC Estimated Results Price of Full Period

\begin{tabular}{|c|c|c|c|}
\hline Variables & $\Delta Q$ atar & $\Delta \mathrm{UAE}$ & $\Delta$ Bahrain \\
\hline \multicolumn{4}{|c|}{ FULL PERIOD } \\
\hline$\Delta$ Qatar $(-1)$ & 0.005 & 0.042 & 0.046 \\
\hline$\triangle \mathrm{UAE}(-1)$ & $0.099^{* * *}$ & 0.016 & $0.039^{* *}$ \\
\hline$\Delta$ Bahrain (-1) & $0.398^{* * *}$ & $0.200^{* * *}$ & $0.053^{* *}$ \\
\hline Res & $1.108^{* * *}$ & $0.970^{* * *}$ & $0.936^{* * *}$ \\
\hline $\mathrm{R}^{2}$-Adj & 0.673 & 0.768 & 0.608 \\
\hline F-Stat & 266.956 & 427.212 & 200.992 \\
\hline Log likelihood & 2776.655 & 2828.312 & 2954.952 \\
\hline SIC & -10.680 & -10.881 & -11.371 \\
\hline \multicolumn{4}{|c|}{ CRISIS PERIOD } \\
\hline$\Delta$ Qatar $(-1)$ & 0.0181 & $0.109^{* * *}$ & $0.092^{* * *}$ \\
\hline$\triangle \mathrm{UAE}(-1)$ & $0.048^{* * *}$ & 0.007 & $0.021^{*}$ \\
\hline$\Delta$ Bahrain $(-1)$ & $0.141^{* * *}$ & $0.073^{* * *}$ & 0.004 \\
\hline Res & $1.004^{* * *}$ & 0.996 & $0.987^{* * *}$ \\
\hline $\mathrm{R}^{2}$-Adj & 0.891 & 0.945 & 0.901 \\
\hline F-Stat & 598.877 & 1262.379 & 673.222 \\
\hline Log likelihood & 1944.675 & 1917.355 & 1982.962 \\
\hline SIC & -13.088 & -12.903 & -13.347 \\
\hline \multicolumn{4}{|c|}{ DECLINED OF SUKUK PRICE } \\
\hline$\Delta$ Qatar (-1) & 0.009 & 0.024 & 0.026 \\
\hline$\triangle \mathrm{UAE}(-1)$ & $0.105^{*}$ & 0.029 & 0.045 \\
\hline$\Delta$ Bahrain $(-1)$ & $0.514^{* * *}$ & $0.277^{* * *}$ & 0.100 \\
\hline Res & $1.183^{* * *}$ & $0.947^{* * *}$ & $0.894^{* * *}$ \\
\hline $\mathrm{R}^{2}$-Adj & 0.581 & 0.674 & 0.460 \\
\hline F-Stat & 76.948 & 114.017 & 47.718 \\
\hline Log likelihood & 1079.670 & 1114.331 & 1172.085 \\
\hline SIC & -9.693 & -10.008 & -10.533 \\
\hline
\end{tabular}

Source: Processed Data

*** at $1 \%$ level of Significance

** at $5 \%$ level of Significance

* at $10 \%$ level of Significance

Negative sign appearing in the influence of Bahrain sukuk price on that of Qatar means that there is a market shock moving in a direction against that of Qatar sukuk price. This situation also applies in the observed full period and the pricedecline period to Bahrain - UAE context 
Table 5 and Table 6 illustrate diversity of the results. Pressure to Sukuk price was indicated with positive signs, while pressure to spread is indicated by negative signs. They imply that when a Sukuk price moves to a particular direction, the other Sukuk would move to the same direction. On the other hand, when a spread of a Sukuk price gets larger, and stimulates liquidity, the other Sukuk would experience smaller spread and enjoy liquidity.

Table 5. VEC Estimated Results Spread of Full Period

\begin{tabular}{llll}
\hline Variables & $\Delta$ Qatar & $\Delta$ UAE & $\Delta$ Bahrain \\
\hline FULL PERIOD & & & \\
$\Delta$ Qatar (-1) & 0.009 & -0.003 & $-0.015^{* * *}$ \\
$\Delta$ UAE (-1) & $0.008^{*}$ & $0.001^{* *}$ & 0.002 \\
$\Delta$ Bahrain (-1) & $-0.051^{* * *}$ & $-0.004^{* * *}$ & -0.001 \\
RES & $1.000^{* * *}$ & $1.000^{* * *}$ & $0.999^{* * *}$ \\
R'-Adj & 0.974 & 0.999 & 0.973 \\
F-Stat & 4752.323 & 1465155 & 4711.108 \\
Log likelihood & 1667.861 & 2838.548 & 1786.278 \\
SIC & -6.392 & -10.920 & -6.850 \\
CRISIS PERIOD & & & \\
$\Delta$ Qatar (-1) & 0.015 & $-0.025^{* *}$ & -0.009 \\
$\Delta$ UAE (-1) & -0.008 & -0.008 & $5.21 \mathrm{E}-05$ \\
$\Delta$ Bahrain (-1) & $-0.024^{*}$ & 0.021 & -0.005 \\
RES & $0.999^{* * *}$ & $0.999^{* * *}$ & 1.000 \\
R$^{2}$-Adj & 0.972 & 0.989 & 0.975 \\
F-Stat & 2514.430 & 6339.700 & 2831.765 \\
Log likelihood & 943.365 & 954.658 & 1054.315 \\
SIC & -6.299 & -6.376 & -7.052 \\
DECLINED OF SUKUK PRICE & & \\
$\Delta$ Qatar (-1) & -0.010 & 0.021 & -0.010 \\
$\Delta$ UAE (-1) & $0.024^{* * *}$ & 0.001 & 0.005 \\
$\Delta$ Bahrain (-1) & $-0.081^{* * *}$ & $-0.065^{* * *}$ & 0.002 \\
RES & $0.996^{* * *}$ & $1.001^{* * *}$ & $0.999^{* * *}$ \\
R ${ }^{2}$-Adj & 0.966 & 0.990 & 0.958 \\
F-Stat & 1549.261 & 5635.951 & 1245.039 \\
Log likelihood & 682.447 & 654.987 & -6.135 \\
SIC & -6.081 & -5.832 & \\
\hline
\end{tabular}

Source: Processed Data

*** at $1 \%$ level of Significance

** at $5 \%$ level of Significance

$*$ at $10 \%$ level of Significance 
Table 6 reveals causality between the observed markets in the full-period observation. Qatar sukuk price stimulates UAE market shock, both in price and spread terms. These proofs are significant at $10 \%$ and 5\% significance level. The reverse is not true. Bahrain Sukuk price triggers price shock in both Qatar and UAE Sukuk markets. Bahrain consistently causes changes in price and spread of UAE Sukuk, both in the context of the observed full period and the observed pricedecline period. The reverse is true. The causality and cointegration tests summarize the strong tie between Bahrain and UAE Sukuk markets, meaning that any Sukuk portfolio involving these two Sukuks is relatively risky. Inclusion of Qatar Sukuk in such portfolio may induce risk-reduction. Moreover, none of the observed Sukuk triggers shock on other Sukuk during the crisis period.

Table 6. Engle Granger Causality Test of Price and Spread for Al Ijarah Sukuk

\begin{tabular}{lll}
\hline SUKUK & CAUSALITY & SIGNIFICANCE \\
\hline Full Period & Qatar $\rightarrow-\rightarrow$ UAE & $2.357^{*}$ \\
Price of Sukuk & Bahrain $\rightarrow-\rightarrow$ Qatar & $3.743^{* *}$ \\
& UAE $-\rightarrow$ Bahrain & $3.071^{* *}$ \\
Spread of Sukuk & Bahrain $--\rightarrow$ UAE & $5.519^{* * *}$ \\
& Qatar $--\rightarrow$ UAE & $3.147^{* *}$ \\
\hline Crisis Period & & \\
Price of Sukuk & & - \\
Spread of Sukuk & & - \\
\hline Declined Of Sukuk Price & & \\
Price of Sukuk & & $2.685^{*}$ \\
Spread of Sukuk & Bahrain $--\rightarrow$ UAE & \\
& & $4.573^{* *}$ \\
& UAE $--\rightarrow$ Qatar & $4.538^{* *}$ \\
& Qatar $--\rightarrow$ UAE & $6.701^{* * *}$ \\
& Bahrain $\rightarrow$ UAE & $3.387^{* *}$ \\
\hline
\end{tabular}

Source: Processed Data

*** at $1 \%$ level of Significance

** at $5 \%$ level of Significance

* at $10 \%$ level of Significance 


\section{Discussion}

Low correlation among the observed Gulf Sukuk markets does not prove good potential for forming low risk Sukuk portfolio using Gulf Sukuks, as the investigation results indicate significant cointegration coefficients, particularly in the longterm. This study also reveals that Bahrain Sukuk market dominates its relationship with the other two Sukuk markets. Investors in Gulf Sukuk markets may want to avoid putting Bahrain Sukuk in their portfolio if they seek for low risk profolio, as this market triggers price and spread changes in the other two markets. Furthermore, results of this study imply that external shock might enter Gulf economies through Bahrain Sukuk market.

Other interesting issue found is that the three Sukuks are vulnerable to financial crisis impact, especially in the long run. It is interesting to know that investors will switch to other Sukuk, particularly of one of the Gulf Sukuks, if financial crisis hits or price of their Sukuks declines. The finding also suggests that investors focus more on Sukuk price rather than on liquidity represented by Bid-Ask spread.

\section{Conclusion}

This study aims to conduct empirical investigation to reveal the causality of credit and liquidity risk on Sukuk Markets in Gulf economies in the period of Greece Financial Crises (2010 to 2013). We employed Granger causality test, with all the associated vector autoregression model procedures, using the Sukuk data. We ran the analysis procedure through three observations, such as: (i) full period observation; (ii) before-crisis data observation; and (iii) during-crisis data to show different perspectives of the impact.

Our findings show that Bahrain sukuk market is cointegrated with those of Qatar and UAE in the full period observation. Meanwhile, during the crisis, Qatar Sukuk market is cointegrated with those of UAE Bahrain. We also find that Bahrain Sukuk triggers market shock in both Qatar and UAE Sukuk markets. Bahrain consistently causes changes in price and spread of UAE Sukuk, both in the context of the full period and the during-crisis period. The reverse is true. There has been strong tie between Bahrain and UAE Sukuk markets

\section{References}

Aboody. D. et.al. (2014). Corporate Bond Returns and The Financial Crisis. Journal of Banking \& Finance. Vol. 40: 42-53.

AuYong, H.H. et.al. (2004). Cointegration and Causality in the Asian and Emerging Foreign Exchange Markets: Evidence from The 1990s Financial Crises. International Review of Financial Analysis. Vol. 13 (4): 479-515. 
Bhala, R. (2012). Handbook of Key Global Financial Markets, Institutions, and Infrastructure. Netherlands: Academic Press.

Febrian, E. \& A. Herwany. (2009). Volatility Forecasting Models and Market CoIntegration: A Study on South-East Asian markets. Indonesia Capital Market Review (ICMR). Vol. 1 (1): 27-42.

Friewald, N. et.al. (2012). Illiquidity or Credit Deterioration: A Study of Liquidity in the US Corporate Bond Market During Financial Crises. Journal of Financial Economics. Vol. 105 (1): 18-36.

Guillaumin, C. (2009). Financial Integration in East Asia: Evidence from Panel Unit Root and Panel Cointegration Tests. Journal of Asian Economics. Vol. 20 (3): 314-326.

Granger, C.W.J. \& J. Hallman. (1991). Long Memory Series with Attractors. Oxford Bulletin of Economics and Statistics. Vol. 53 (1): 11-26.

Herwany, A. \& E. Febrian, (2008). Co-integration and Causality Analysis on Developed Asian markets for Risk Management \& Portfolio Selection. Gadjahmada International Journal of Business. Vol. 10 (3): 285-312.

Kumar, R. (2014). Strategies of Banks and Other Financial Institutions: Netherlands: Academic Press.

Pragidis, I.C. et.al. (2015). Contagion Effects During Financial Crisis: Evidence from The Greek Sovereign Bonds Market. Journal of Financial Stability. Vol. 18: 127-138.

Shin, D. \& B. Kim. (2015). Liquidity and Credit Risk Before and After the Global Financial Crisis: Evidence from the Korean Corporate Bond Market. PacificBasin Finance Journal. Vol. 33: 38-61.

Stiglitz, J. (2012). The price of inequality. United Kingdom: Penguin.

Zakaria, N.B. et.al. (2012). The Construct of Sukuk, Rating and Default Risk. The International Congress on Interdisciplinary Business and Social Science 2012 (ICIBSoS 2012), Jakarta. 